\title{
BILANGAN DOMINATOR CHROMATIC PADA GRAF CYCLE, ANTIPRISMA DAN PRISMA
}

\author{
Tomipatra, Evi Noviani, Fransiskus Fran
}

\begin{abstract}
INTISARI
Diberikan graf $G=(V, E)$, dominator coloring merupakan pewarnaaan simpul (proper coloring) sehingga simpul-simpul graf $G$ mendominasi setiap simpul pada beberapa kelas warna. Jumlah kelas warna minimum yang diperlukan dalam dominator coloring graf $G$ disebut bilangan dominator chromatic graf $G$ dinotasikan dengan $\chi_{d}(G)$. Penelitian ini dibahas tentang bilangan dominator chromatic dari graf $G$ dengan $G$ adalah graf cycle, antiprisma dan prisma. Graf antiprisma dinotasikan dengan $A_{n}$ merupakan graf yang dibangun dari dua buah graf cycle dengan $n$ simpul dan graf prisma dinotasikan dengan $P_{(n, 3)}$ merupakan graf yang dibangun dari graf cycle dan graf lintasan dengan $n$ simpul. Berdasarkan penelitian ini diperoleh bahwa bilangan dominator chromatic pada graf cycle $C_{n}$ yaitu 2 untuk $n=4,3$ untuk $n=5$ dan $\left\lceil\frac{n}{3}\right\rceil+2$ untuk $n \geq 6$ dan $n=3$, bilangan dominator chromatic pada graf antiprisma $A_{n}$ yaitu 3 untuk $n=3,4$ untuk $n=4,5$ untuk $n=5$ dan $\left\lfloor\frac{n}{2}\right\rfloor+3$ untuk $n \geq$ 6 dan bilangan dominator chromatic pada graf prisma $P_{(n, 3)}$ yaitu 3 untuk $n=1,2$ dan $n+2$ untuk $n \geq 3$.
\end{abstract}

Kata Kunci: himpunan dominasi, pewarnaaan simpul, dominator coloring.

\section{PENDAHULUAN}

Teori tentang dominasi (dominating) pada graf dimulai pada awal tahun 1850 sejak pemain catur di Benua Eropa antusias untuk menyelesaikan masalah dominating queens [1]. Dalam masalah ini, dominasi digunakan untuk menentukan banyaknya langkah queen, sehingga setiap queen bisa mendominasi atau menyerang setiap posisi dengan sekali perpindahan pada papan catur berukuran $8 \times 8$. Kemudian konsep tentang himpunan dominasi dimulai pada tahun 1960an, dan sejak saat itu penelitian terkait himpunan dominasi berkembang cukup pesat. Himpunan simpul $S$ adalah himpunan dominasi jika untuk setiap simpul $u \in V-S, u$ bertetangga dengan setidaknya satu simpul dalam $S$. Bilangan dominasi $\gamma(G)$ adalah kardinalitas minimum di antara semua himpunan yang mendominasi dalam $G$ [1]. Banyak manfaat dari himpunan dominasi dalam kehidupan sehari-hari, diantaranya yaitu untuk memodelkan keterkaitan pada jaringan komunikasi komputer, teori jejaring sosial, dan masalah serupa lainnya [2].

Pokok bahasan dalam teori graf yang memiliki banyak manfaat dalam kehidupan sehari-hari salah satunya yaitu pewarnaan simpul. Pewarnaan simpul diartikan sebagai proses memberi warna pada setiap simpul graf sehingga dua simpul yang bertetangga memiliki warna yang berbeda [3]. Banyaknya warna minimum yang digunakan untuk mewarnai graf $G$ disebut bilangan kromatik dinotasikan dengan $\chi(G)$. Pewarnaan simpul dalam teori graf dapat diaplikasikan dalam berbagai masalah kehidupan sehari-hari, beberapa diantaranya yakni penjadwalan kuliah [4] dan pengaturan lampu lalu lintas [5].

Jika konsep himpunan dominasi dan konsep pewarnaan simpul dipadukan maka akan mendapatkan konsep baru yaitu konsep dominator coloring. Konsep dominator coloring pertama kali diperkenalkan oleh Relucca Gera pada tahun 2006. Dominator coloring diartikan sebagai pewarnaan 
simpul sehingga simpul-simpul pada graf dapat mendominasi setiap simpul pada beberapa kelas warna. Jumlah minimum dari kelas warna pada dominator coloring graf $G$ disebut bilangan dominator chromatic dari graf $G$ dan dinotasikan $\chi_{d}(G)$. Dominator coloring memiliki beberapa aplikasi salah satunya pada penggunaan bilangan dominator chromatic dalam perumusan masalah penjadwalan open shop untuk memberikan model penjadwalan yang lebih akurat dalam masalah penjadwalan yang sering muncul secara luas diberbagai aplikasi industri [6].

Graf cycle merupakan graf sederhana yang setiap simpulnya berderajat dua dan tidak memiliki sisi ganda, dari graf cycle tersebut dapat dibangun sebuah graf, beberapa diantaranya yaitu graf antiprisma dan prisma. Graf antiprisma adalah graf yang terbentuk dari dua graf cycle luar dan dalam yang setiap simpulnya saling terhubung, sedangkan graf prisma adalah graf yang terbentuk dari hasil kali Kartesius graf cycle dan lintasan. Penelitian terkait bilangan dominator chromatic pada kedua graf tersebut belum pernah dibahas pada penelitian lainnya. Terkait hal tersebut, maka akan dilakukan penelitian bilangan dominator chromatic pada graf antiprisma dan prisma. Namun, sebelumnya akan dikaji terlebih dahulu bilangan dominator chromatic pada graf yang membangun graf-graf tersebut yaitu bilangan dominator chromatic pada graf cycle.

\section{HIMPUNAN DOMINASI}

Secara historis, masalah dominasi mulai dipelajari dari tahun 1960an [1]. Suatu himpunan simpul S disebut himpunan dominasi untuk graf $G$ jika untuk setiap $u \in V(G)$ maka $u \in S$ atau $u$ bertetangga dengan minimal sebuah simpul di $S$. Kardinalitas minimal dari suatu himpunan dominasi pada suatu graf $G$ disebut bilangan dominasi. Suatu himpunan dominasi disebut himpunan dominasi minimal jika tidak ada himpunan bagiannya (kecuali dirinya sendiri) yang juga merupakan himpunan dominasi.

Definisi 1. [1] Himpunan simpul $S$ adalah himpunan dominasi jika untuk setiap simpul $u \in V-S$, $u$ bertetangga dengan setidaknya satu simpul dalam $S$. Bilangan dominasi $\gamma(G)$ adalah kardinalitas minimum di antara semua himpunan yang mendominasi dalam $G$.

Berikut ilustrasi diberikan contoh dominasi pada graf seperti Gambar 1 berikut.

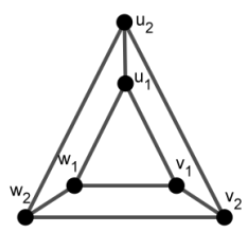

\section{Gambar 1 Dominasi graf}

Berdasarkan Gambar 1, himpunan simpul yang mendominasi graf tersebut adalah $S_{1}=\left\{u_{1}, v_{2}\right\}$, $S_{2}=\left\{v_{1}, w_{2}\right\}$ dan $S_{3}=\left\{w_{1}, u_{2}\right\}$. Karena setiap himpunan simpul memiliki jumlah kardinalitas minimum yaitu 2 . Jadi bilangan dominasi $\gamma(G)=2$.

\section{PEWARNAAN SIMPUL}

Pewarnaan graf merupakan salah satu topik dalam teori graf yang banyak digunakan untuk mengatasi berbagai masalah dalam kehidupan sehari-hari. Pewarnaan graf memiliki kasus dalam pelabelannya. Pelabelan yang dimaksud adalah pemberian warna pada simpul ataupun sisi dengan batas dan aturan tertentu. Pemberian warna dalam graf dapat menggunakan himpunan warna atau himpunan bilangan asli pada setiap simpul maupun sisi. Dalam pembahasan ini hanya membahas pewarnaan simpul, untuk penjelasan lebih lengkap mengenai pewarnaan simpul diberikan definisi berikut. 
Definisi 2. [7] Pewarnaan simpul adalah memberi warna pada setiap simpul-simpul di dalam graf sedemikian sehingga setiap dua simpul bertetangga mempunyai warna berbeda.

Berikut ilustrasi contoh pewarnaan simpul seperti Gambar 2 berikut.

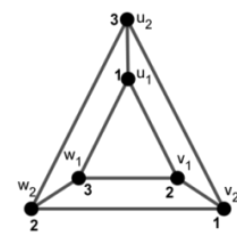

\section{Gambar 2 Pewarnaan simpul}

Berdasarkan Gambar 2, pewarnaan simpul tersebut mengunakan tiga warna yaitu warna satu dengan himpunan simpul $V_{1}=\left\{u_{1}, v_{2}\right\}$, warna dua dengan himpunan simpul $V_{2}=\left\{v_{1}, w_{2}\right\}$ dan warna tiga dengan himpunan simpul $V_{3}=\left\{w_{1}, u_{2}\right\}$.

Pewarnaan simpul pada graf bukan hanya mewarnai setiap simpul yang bertetangga dengan warna yang berbeda, melainkan menginginkan jumlah warna minimum. Jumlah warna minimum yang digunakan untuk mewarnai simpul disebut bilangan kromatik pada graf $G$, dinotasikan dengan $\chi(G)$ [7]. Seperti pada Gambar 2, bilangan kromatiknya $\chi(G)=3$.

\section{DOMINATOR COLORING}

Dominator coloring merupakan perpaduan antara konsep pewarnaan simpul dan himpunan dominasi. Konsep dominator coloring dan bilangan dominator chromatic pada graf pertama kali diperkenalkan oleh Gera pada tahun 2006 [8], sejak pertama kali diperkenalkan dominator coloring mempunyai kajian yang terus menerus berkembang cukup pesat, hasil konsep ini banyak dikembangkan dalam aplikasi dominasi pada jaringan.

Penjelasan lebih lengkap dijelaskan berdasarkan definisi-definisi berikut.

Definisi 3. [9] Diberikan graf $G=(V, E)$, dominator coloring adalah pewarnaan simpul dengan setiap simpul pada graf $G$ mendominasi semua simpul pada beberapa kelas warna $K_{i}$. Bilangan dominator chromatic $\chi_{d}(G)$ adalah jumlah minimum kelas warna yang diperlukan untuk dominator coloring di G.

Berdasarkan Definisi 3, akibatnya suatu graf akan memenuhi suatu kondisi Observasi 4 berikut.

Observasi 4. [9] Diberikan suatu graf $G$, maka $\chi_{d}(G) \geq \chi(G)$.

Berikut disajikan pewarnaan simpul berdasarkan Definisi 3.

Contoh 5. Diberikan pewarnanan graf $G$ pada Gambar 3 sebagai berikut.

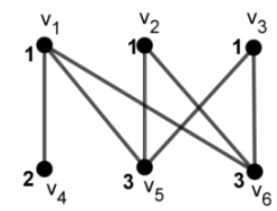

\section{Gambar 3 Pewarnaan graf $G$}

Pada Gambar 3, untuk menentukan jumlah warna pada graf terlebih dahulu ditentukan himpunan dominasinya. Diperolah $S=\left\{v_{1}, v_{2}, v_{3}\right\}$ adalah himpunan yang mendominasi graf $G$ pada Gambar 3, sehingga simpul pada $\left\{v_{1}, v_{2}, v_{3}\right\}$ dapat diberikan warna 1 untuk kelas warna $K_{1}$. Simpul pada $\left\{v_{4}, v_{5}, v_{6}\right\}$ tidak dapat dikelompokkan dalam kelas warna yang sama, karena simpul $\left\{v_{4}\right\}$ tidak dapat mendominasi semua simpul dalam kelas warna $K_{1}$. Untuk itu, simpul $\left\{v_{4}\right\}$ diberikan warna 2 untuk kelas warna berbeda yaitu kelas warna $K_{2}$, dan simpul $\left\{v_{5}, v_{6}\right\}$ diberikan warna 3 untuk kelas warna $K_{3}$, karena setiap simpul yang bertetangga memiliki warna yang berbeda maka Gambar 3 merupakan 
pewarnaan simpul dengan 3 kelas warna. Jadi kelas warna pada Gambar 3 adalah $K_{1}=\left\{v_{1}, v_{2}, v_{3}\right\}, K_{2}$ $=\left\{v_{4}\right\}$, dan $K_{3}=\left\{v_{5}, v_{6}\right\}$.

Selanjutnya, dari Tabel 4 ditunjukkan setiap simpul graf $G$ pada Gambar 3 dapat mendominasi beberapa kelas warna.

Tabel 4. Dominasi simpul untuk kelas warna pada Gambar 3

\begin{tabular}{cc}
\hline Simpul & $\begin{array}{c}\text { Kelas Warna yang } \\
\text { Didominasi }\end{array}$ \\
\hline$v_{1}$ & $K_{3}, K_{2}$ \\
\hline$v_{2}$ & $K_{3}$ \\
\hline$v_{3}$ & $K_{3}$ \\
\hline$v_{4}$ & $K_{2}$ \\
\hline$v_{5}$ & $K_{1}$ \\
\hline$v_{6}$ & $K_{1}$ \\
\hline
\end{tabular}

Berdasarkan Tabel 4, dapat dilihat bahwa Gambar 3 merupakan dominator coloring, karena dapat mendominasi beberapa kelas warna pada graf $G$. Jadi bilangan dominator chromatic pada graf $G$ adalah 3 atau $\chi_{d}(G)=3$.

Graf khusus yang dibahas pada penelitian ini adalah graf cycle, antiprisma dan prisma. Graf cycle merupakan graf sederhana yang setiap simpulnya berderajat dua, dengan $n$ simpul dilambangkan dengan $C_{n}$ [7]. Graf antiprisma $A_{n}$ dengan $n \geq 3$ adalah suatu graf yang berderajat empat dengan jumlah simpul $2 n$ dan jumlah sisi $4 n$. Graf antiprisma tersusun atas $C_{n}$ luar dan dalam, kemudian antara kedua cycle dihubungkan oleh sisi $u_{i} v_{i}$ dan $u_{i} v_{i+i(\bmod n)}$ dengan $i=1,2,3, \ldots, n$ [10]. Graf prisma untuk $m \geq 3$ dan $n \geq 1$ adalah graf hasil kali Kartesius $P_{(n, m)}=C_{m} \times P_{n}$ dengan $P_{n}$ adalah sebuah lintasan dengan $n$ titik dan $C_{m}$ adalah graf cycle dengan $m$ titik [11]. Berikut diberikan ilustrasi graf-graf tersebut.

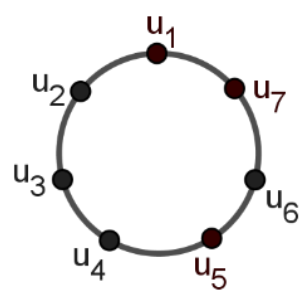

(a)

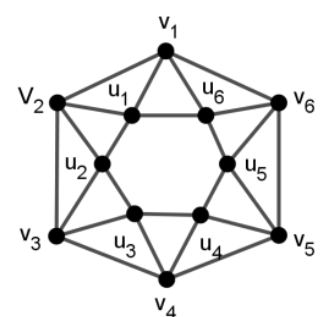

(b)

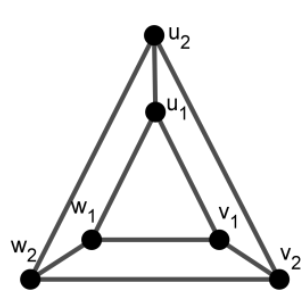

(c)

Gambar 5 (a) Graf cycle $C_{7}$, (b) Graf antiprisma $A_{6}$ dan (c) Graf prisma $P_{(2,3)}$

\section{Dominator Coloring pada Graf Cycle}

Adapun bilangan dominator chromatic pada graf cycle dengan $n$ simpul, dikaji pada Teorema 6 sebagai berikut.

Teorema 6. [9] Jika diberikan graf cycle $C_{n}$ untuk $n \geq 3$, maka :

$$
\chi_{d}\left(C_{n}\right)=\left\{\begin{array}{cc}
2, & n=4 \\
3, & n=5 \\
\left\lceil\frac{n}{3}\right\rceil+2, & n \geq 6 \text { dan } n=3 .
\end{array}\right.
$$

Bukti: Diberikan graf cycle $C_{n}$ untuk $n \geq 4$, berdasarkan definisi graf cycle diketahui setiap simpul berderajat 2 dengan himpunan simpul $V\left(C_{n}\right)=\left\{u_{1}, u_{2}, u_{3}, \ldots, u_{n}\right\}$, sehingga pada pembuktian ini dapat dibagi menjadi tiga kasus. 
Kasus 1: Untuk $n=4$

Pada graf cycle $C_{4}$, diperoleh himpunan simpul yang mendominasi yaitu $S_{1}=\left\{u_{1}, u_{3}\right\}$ dan $S_{2}=\left\{u_{2}, u_{4}\right\}$. Selanjutnya, elemen simpul $S_{1}$ diberi warna 1 sehingga diperoleh kelas warna $K_{1}$ dan elemen simpul $S_{2}$ diberi warna 2 sehingga diperoleh kelas warna $K_{2}$. Karena setiap simpul yang bertetangga memiliki warna yang berbeda maka pewarnaan tersebut merupakan pewarnaan simpul dengan $\chi\left(C_{4}\right)=2$. Akibatnya, berdasarkan Observasi 4 diperoleh $\chi_{d}\left(C_{4}\right) \geq 2$. Lebih lanjut, dari kelas warna yang diperoleh, untuk simpul $u_{1}, u_{3}$ dapat mendominasi setiap simpul di kelas warna $K_{2}$ dan simpul $u_{2}, u_{4}$ dapat mendominasi setiap simpul di kelas warna $K_{1}$. Jadi setiap simpul dapat mendominasi beberapa kelas warna, yang artinya pewarnaan yang diperoleh merupakan dominator coloring. Akibatnya, berdasarkan Definisi 3 diperoleh $\chi_{d}\left(C_{4}\right) \leq 2$. Oleh karena $\chi_{d}\left(C_{4}\right) \geq 2$ dan $\chi_{d}\left(C_{4}\right) \leq 2$ maka terbukti $\chi_{d}\left(C_{4}\right)=2$.

Kasus 2: Untuk $n=5$

Pada graf cycle $C_{5}$ diperoleh himpunan simpul yang mendominasi yaitu $S_{1}=\left\{u_{1}, u_{3}\right\}$ dan $S_{2}=\left\{u_{2}, u_{4}\right\}$. Selanjutnya, elemen simpul $S_{1}$ diberi warna 1 sehingga diperoleh kelas warna $K_{1}$ dan elemen simpul $S_{2}$ diberi warna 2 sehingga diperoleh kelas warna $K_{2}$. Untuk simpul yang tersisa yaitu $u_{5}$ belum terwarnai, simpul tersebut diberi warna berbeda yaitu 3 , sehingga diperoleh kelas warna $K_{3}$. Karena setiap simpul yang bertetangga memiliki warna yang berbeda maka pewarnaan tersebut merupakan pewarnaan simpul dengan $\chi\left(C_{5}\right)=3$. Akibatnya, berdasarkan Observasi 4 diperoleh $\chi_{d}\left(C_{5}\right) \geq 3$. Lebih lanjut, dari kelas warna yang diperoleh, untuk simpul $u_{1}, u_{5}, u_{4}$ dapat mendominasi setiap simpul di kelas warna $K_{3}$, simpul $u_{2}$ dapat mendominasi setiap simpul di kelas warna $K_{1}$ dan simpul $u_{3}$ dapat mendominasi setiap simpul di kelas warna $K_{2}$. Jadi setiap simpul dapat mendominasi beberapa kelas warna, yang artinya pewarnaan yang diperoleh merupakan dominator coloring. Akibatnya, berdasarkan Definisi 3 diperoleh $\chi_{d}\left(C_{5}\right) \leq 3$. Oleh kerena $\chi_{d}\left(C_{5}\right) \geq 3$ dan $\chi_{d}\left(C_{5}\right) \leq 3$ maka terbukti $\chi_{d}\left(C_{4}\right)=3$.

Kasus 3: Untuk $n \geq 6$ dan $n=3$

Berdasarkan prosses pewarnaan simpul pada graf cycle, untuk $n=3 k, n=3 k+1$ dan $n=3 k+2$ proses pewarnaan simpulnya berbeda sehingga untuk pembuktian ini dibagi menjadi tiga subkasus.

Subkasus $n=3 k$

Pada graf cycle $C_{n}$ setiap simpul pada graf cycle diberi warna, untuk simpul dengan indeks $i \equiv$ $1(\bmod 6)$ atau $i \equiv 3(\bmod 6)$ untuk $i=1,2, \ldots, n$ diberi warna 1 sehingga diperoleh himpunan kelas warna $K_{1}=\left\{u_{i} \mid i \equiv 1(\bmod 6), i \equiv 3(\bmod 6)\right.$ dan $\left.i \neq n\right\}$, untuk simpul dengan indeks $i \equiv 0(\bmod 6)$ atau $i \equiv 4(\bmod 6)$ diberi warna 2 sehingga diperoleh himpunan kelas warna $K_{2}=\left\{u_{i} \mid i \equiv\right.$ $0(\bmod 6), i \equiv 4(\bmod 6) d a n i=n\}$. Untuk simpul-simpul yang tersisa yaitu $u_{2}, u_{5}, u_{8}, \ldots, u_{3 k-1}$ untuk $1 \leq k \leq\left\lceil\frac{n}{3}\right\rceil$ belum terwarnai, masing-masing simpul diberi warna berbeda yaitu $3,4, \ldots,\left\lceil\frac{n}{3}\right\rceil+2$ sehingga diperoleh kelas warna $K_{3}=\left\{u_{2}\right\}, K_{4}=\left\{u_{5}\right\}, \ldots, K_{\left\lceil\frac{n}{3} \mid+2\right.}=\left\{u_{3 k-1}\right\}$.

Subkasus $n=3 k+1$

Pada graf cycle $C_{n}$ setiap simpul pada graf cycle diberi warna, untuk simpul dengan indeks $i \equiv$ $1(\bmod 6)$ atau $i \equiv 3(\bmod 6)$ untuk $i=1,2, \ldots, n$ diberi warna 1 sehingga diperoleh himpunan kelas warna $K_{1}=\left\{u_{i} \mid i \equiv 1(\bmod 6), i \equiv 3(\bmod 6)\right.$ dan $\left.i \neq n\right\}$, untuk simpul dengan indeks $i \equiv 0(\bmod 6)$ atau $i \equiv 4(\bmod 6)$ diberi warna 2 sehingga diperoleh himpunan kelas warna $K_{2}=\left\{u_{i} \mid i \equiv\right.$ $0(\bmod 6), i \equiv 4(\bmod 6) d a n i \neq n\}$. Untuk simpul-simpul yang tersisa yaitu $u_{2}, u_{5}, u_{8}, \ldots, u_{3 k-1}$ untuk $1 \leq k \leq\left\lceil\frac{n}{3}\right\rceil-1$ dan $u_{n}$ belum terwarnai, masing-masing simpul diberi warna berbeda yaitu $3,4, \ldots,\left\lceil\frac{n}{3}\right\rceil+2$ sehingga diperoleh kelas warna $K_{3}=\left\{u_{2}\right\}, K_{4}=\left\{u_{5}\right\}, \ldots, K_{\left\lceil\frac{n}{3}\right]+2}=\left\{u_{n}\right\}$. 
Subkasus $n=3 k+2$

Pada graf cycle $C_{n}$ setiap simpul pada graf cycle diberi warna, untuk simpul dengan indeks $i \equiv$ $1(\bmod 6)$ atau $i \equiv 3(\bmod 6)$ untuk $i=1,2, \ldots, n$ diberi warna 1 sehingga diperoleh himpunan kelas warna $K_{1}=\left\{u_{i} \mid i \equiv 1(\bmod 6), i \equiv 3(\bmod 6)\right\}$, untuk simpul dengan indeks $i \equiv 0(\bmod 6)$ atau $i \equiv 4(\bmod 6)$ diberi warna 2 sehingga diperoleh himpunan kelas warna $K_{2}=\left\{u_{i} \mid i \equiv 0(\bmod 6), i \equiv\right.$ $4(\bmod 6)\}$. Untuk simpul-simpul yang tersisa yaitu $u_{2}, u_{5}, u_{8}, \ldots, u_{3 k-1}$ untuk $1 \leq k \leq\left\lceil\frac{n}{3}\right\rceil$ belum terwarnai, masing-masing simpul diberi warna berbeda yaitu $3,4, \ldots,\left\lceil\frac{n}{3}\right\rceil+2$ sehingga diperoleh kelas warna $K_{3}=\left\{u_{2}\right\}, K_{4}=\left\{u_{5}\right\}, \ldots, K_{\left\lceil\frac{n}{3}\right\rceil+2}=\left\{u_{3 k-1}\right\}$

Jadi kelas warna yang diperoleh dari graf cycle $C_{n}$ yaitu $K_{1}, K_{2}, K_{3}, K_{4}, \ldots, K_{\left[\frac{n}{3}\right]+2}$. Dari kelas warna yang diperoleh simpul $u_{1}$ dapat mendominasi $K_{3}, u_{2}$ dapat mendominasi $K_{3}, u_{3}$ dapat mendominasi $K_{3}$ dan seterusnya $u_{n}$ dapat mendominasi $K_{\left[\frac{n}{3}\right]+2}$. Hal tersebut berarti pewarnaan yang didefinisikan merupakan dominator coloring. Akibatnya, berdasarkan Definisi 3 diperoleh $\chi_{d}\left(C_{n}\right) \leq\left\lceil\frac{n}{3}\right\rceil+2$. Selanjutnya, akan ditunjukkan bilangan dominator chromatic pada graf cycle yaitu $\chi_{d}\left(C_{n}\right)=\left\lceil\frac{n}{3}\right\rceil+2$. Andaikan $\chi_{d}\left(C_{n}\right)=\left\lceil\frac{n}{3}\right\rceil+1$ maka terdapat $\left\lceil\frac{n}{3}\right\rceil+1$ kelas warna pada graf cycle. Akibatnya, pada salah satu kelas warna $K_{j}$ untuk $j=3,4 \ldots,\left\lceil\frac{n}{3}\right\rceil+1$ terdapat salah satu $j$ dengan $\left|K_{j}\right|=2$ dan untuk $j$ lainnya $\left|K_{j}\right|=1$. Tanpa mengurangi keumuman, misalkan $K_{3}=\left\{u_{l}, u_{m}\right\}$ untuk $l \neq m$ dengan $l, m=$ $2,5,8, \ldots, 3 k-1$ maka simpul $u_{l}, u_{m}$ tidak dapat mendominasi kelas warna manapun. Hal tersebut kontradiksi dengan Definisi 3. Jadi terbukti $\chi_{d}\left(C_{n}\right)=\left\lceil\frac{n}{3}\right\rceil+2$.

\section{Dominator Coloring pada Graf Antiprisma}

Graf antiprisma dengan jumlah simpul $2 n$ memiliki pola bilangan dominator chromatic sehingga diperoleh Proposisi 7 berikut.

Proposisi 7. Jika diberikan graf antiprisma $A_{n}$ untuk $n \geq 3$, maka $\chi_{d}\left(A_{n}\right)=\left\{\begin{array}{cl}3, & n=3 \\ 4, & n=4 \\ 5, & n=5 \\ \left\lfloor\frac{n}{2}\right\rfloor+3, & n \geq 6\end{array}\right.$

Bukti: Diberikan graf antiprisma $A_{n}$ untuk $n \geq 3$, berdasarkan definisi graf antiprisma diketahui setiap simpul berderajat 4 dengan jumlah simpul $2 n$ terdiri dari himpunan simpul $V\left(A_{n}\right)=$ $\left\{u_{1}, u_{2}, u_{3}, \ldots, u_{n}, v_{1}, v_{2}, v_{3}, \ldots, v_{n}\right\}$, sehingga pada pembuktian ini dapat dibagi menjadi empat kasus.

Kasus 1: Untuk $n=3$

Pada graf graf antiprisma $A_{3}$ diperoleh himpunan simpul yang mendominasi yaitu $S_{1}=\left\{u_{1}, v_{3}\right\}$, $S_{2}=\left\{u_{2}, v_{1}\right\}$ dan $S_{3}=\left\{u_{3}, v_{2}\right\}$. Selanjutnya, elemen simpul $S_{1}$ diberi warna 1 sehingga diperoleh kelas warna $K_{1}$, elemen simpul $S_{2}$ diberi warna 2 sehingga diperoleh kelas warna $K_{2}$ dan elemen simpul $S_{3}$ diberi warna 3 sehingga diperoleh kelas warna $K_{3}$. Karena setiap simpul yang bertetangga memiliki warna yang berbeda maka pewarnaan tersebut merupakan pewarnaan simpul dengan $\chi\left(A_{3}\right)=3$. Akibatnya, berdasarkan Observasi 4 diperoleh $\chi_{d}\left(A_{3}\right) \geq 3$. Lebih lanjut, dari kelas warna yang diperoleh, untuk simpul $u_{2}, v_{2}$ dapat mendominasi setiap simpul di kelas warna $K_{1}$, simpul $u_{3}, v_{3}$ dapat mendominasi setiap simpul di kelas warna $K_{2}$ dan simpul $u_{1}, v_{1}$ dapat mendominasi setiap simpul di kelas warna $K_{3}$. Jadi setiap simpul dapat mendominasi beberapa kelas warna, yang artinya pewarnaan yang diperoleh merupakan dominator coloring. Akibatnya, berdasarkan Definisi 3 diperoleh $\chi_{d}\left(A_{3}\right) \leq 3$. Oleh karena $\chi_{d}\left(A_{3}\right) \geq 3$ dan $\chi_{d}\left(A_{3}\right) \leq 3$ maka terbukti $\chi_{d}\left(A_{3}\right)=3$. 
Kasus 2: Untuk $n=4$

Pada graf graf antiprisma $A_{4}$ diperoleh himpunan simpul yang mendominasi yaitu $S_{1}=\left\{u_{1}, u_{3}\right\}$, $S_{2}=\left\{u_{2}, u_{4}\right\}, S_{3}=\left\{v_{1}, v_{3}\right\}$ dan $S_{4}=\left\{v_{2}, v_{3}\right\}$. Selanjutnya, elemen simpul $S_{1}$ diberi warna 1 sehingga diperoleh kelas warna $K_{1}$, elemen simpul $S_{2}$ diberi warna 2 sehingga diperoleh kelas warna $K_{2}$, elemen simpul $S_{3}$ diberi warna 3 sehingga diperoleh kelas warna $K_{3}$ dan elemen simpul $S_{4}$ diberi warna 4 sehingga diperoleh kelas warna $K_{4}$. Karena setiap simpul yang bertetangga memiliki warna yang berbeda maka pewarnaan tersebut merupakan pewarnaan simpul dengan $\chi\left(A_{4}\right)=4$. Akibatnya, berdasarkan Observasi 4 diperoleh $\chi_{d}\left(A_{4}\right) \geq 4$. Lebih lanjut, dari kelas warna yang diperoleh, untuk simpul $u_{2}, u_{4}$ dapat mendominasi setiap simpul di kelas warna $K_{1}$, simpul $u_{1}, u_{3}$ dapat mendominasi setiap simpul di kelas warna $K_{2}$, simpul $v_{2}, v_{4}$ dapat mendominasi setiap simpul di kelas warna $K_{3}$ dan simpul $v_{1}, v_{3}$ dapat mendominasi setiap simpul di kelas warna $K_{4}$. Jadi setiap simpul dapat mendominasi beberapa kelas warna, yang artinya pewarnaan yang diperoleh merupakan dominator coloring. Akibatnya, berdasarkan Definisi 3 diperoleh $\chi_{d}\left(A_{4}\right) \leq 4$. Oleh karena $\chi_{d}\left(A_{4}\right) \geq 4$ dan $\chi_{d}\left(A_{4}\right) \leq 4$ maka terbukti $\chi_{d}\left(A_{4}\right)=4$.

Kasus 3: Untuk $n=5$

Pada graf antiprisma $A_{4}$ diperoleh himpunan simpul yaitu $S_{1}=\left\{u_{4}, v_{3}\right\}, S_{2}=\left\{u_{3}, v_{2}\right\}, S_{3}=\left\{u_{5}, v_{4}\right\}$, $S_{4}=\left\{u_{1}, v_{5}\right\}$ dan $S_{5}=\left\{u_{2}, v_{1}\right\}$. Selanjutnya, elemen simpul $S_{1}$ diberi warna 1 sehingga diperoleh kelas warna $K_{1}$, elemen simpul $S_{2}$ diberi warna 2 sehingga diperoleh kelas warna $K_{2}$, elemen simpul $S_{3}$ diberi warna 3 sehingga diperoleh kelas warna $K_{3}$, elemen simpul $S_{4}$ diberi warna 4 sehingga diperoleh kelas warna $K_{4}$ dan elemen simpul $S_{5}$ diberi warna 5 sehingga diperoleh kelas warna $K_{5}$. Karena setiap simpul yang bertetangga memiliki warna yang berbeda maka pewarnaan tersebut merupakan pewarnaan simpul dengan $\chi\left(A_{5}\right)=5$. Akibatnya, berdasarkan Observasi 4 diperoleh $\chi_{d}\left(A_{5}\right) \geq 5$. Lebih lanjut, dari kelas warna yang diperoleh, untuk simpul $u_{3}, v_{4}$ dapat mendominasi setiap simpul di kelas warna $K_{1}$, simpul $u_{2}, v_{3}$ dapat mendominasi setiap simpul di kelas warna $K_{2}$, simpul $u_{4}, v_{5}$ dapat mendominasi setiap simpul di kelas warna $K_{3}$, simpul $u_{5}, v_{1}$ dapat mendominasi setiap simpul di kelas warna $K_{4}$ dan simpul $u_{1}, v_{2}$ dapat mendominasi setiap simpul di kelas warna $K_{5}$. Jadi setiap simpul dapat mendominasi beberapa kelas warna, yang artinya pewarnaan yang diperoleh merupakan dominator coloring. Akibatnya, berdasarkan Definisi 3 diperoleh $\chi_{d}\left(A_{5}\right) \leq 5$. Oleh kerena $\chi_{d}\left(A_{5}\right) \geq 5$ dan $\chi_{d}\left(A_{5}\right) \leq 5$ maka terbukti $\chi_{d}\left(A_{5}\right)=5$.

Kasus 4 : Untuk $n \geq 6$

Berdasarkan definisi graf cycle, proses pemberian warna pada $n$ simpul genap dan $n$ simpul ganjil berbeda sehingga untuk pembuktian ini dibagi menjadi dua subkasus.

Subkasus $n$ genap

Dari graf $A_{n}$, diperoleh himpunan simpul yang mendominasi graf $A_{n}$ yaitu $S_{1}=\left\{u_{1}, u_{3}, u_{5} \ldots, u_{2\left\lfloor\frac{n}{2}\right\rfloor-1}\right\}, S_{2}=\left\{u_{2}, u_{4}, u_{6}, \ldots, u_{2\left\lfloor\frac{n}{2}\right]}\right\}$ dan $S_{3}=\left\{v_{1}, v_{3}, v_{5}, \ldots, v_{2\left\lfloor\frac{n}{2}\right\rfloor-1}\right\}$. Selanjutnya, elemen-elemen simpul $S_{1}$ diberi warna 1 sehingga diperoleh kelas warna $K_{1}$, elemen-elemen simpul $S_{2}$ diberi warna 2 sehingga diperoleh kelas warna $K_{2}$ dan elemen-elemen simpul $S_{3}$ diberi warna 3 sehingga diperoleh kelas warna $K_{3}$. Untuk simpul-simpul yang tersisa yaitu $v_{2}, v_{4}, \ldots, v_{2}\left\lfloor\frac{n}{2}\right\rfloor$ belum terwarnai, masing-masing simpul diberi warna berbeda yaitu $4,5, \ldots,\left\lfloor\frac{n}{2}\right\rfloor+3$ sehingga diperoleh kelas warna $K_{4}=\left\{v_{2}\right\}, K_{5}=\left\{v_{4}\right\}, \ldots, K_{\left\lfloor\frac{n}{2}\right\rfloor+3}=\left\{v_{2}\left[\frac{n}{2}\right]\right\}$. Jadi kelas warna yang diperoleh dari graf antiprisma $A_{n}$ yaitu $K_{1}, K_{2}, K_{3}, K_{4}, \ldots, K_{\left[\frac{n}{2}\right\rfloor+3}$. Dari kelas warna yang diperoleh simpul $u_{1}, v_{1}$ dapat mendominasi $K_{4}$, simpul $u_{2}, v_{2}$ dapat mendominasi $K_{4}$, simpul $u_{3}, v_{3}$ dapat mendominasi $K_{5}$ dan seterusnya simpul 
$u_{n}, v_{n}$ dapat mendominasi $K_{\left(\frac{n}{2}\right)+3}$ artinya, pewarnaan yang diperoleh merupakan dominator coloring. Akibatnya,berdasarkan Definisi 3 diperoleh $\chi_{d}\left(A_{n}\right) \leq\left\lfloor\frac{n}{2}\right\rfloor+3$.

Subkasus $n$ ganjil

Dari graf antiprisma $A_{n}$ diperoleh himpunan simpul yang mendominasi graf $A_{n}$ yaitu $S_{1}=$ $\left\{u_{1}, u_{3}, u_{5} \ldots, u_{2\left(\left[\frac{n}{2}\right]\right)-1}, v_{n}\right\}$, dan $S_{2}=\left\{u_{2}, u_{4}, u_{6}, \ldots, u_{2\left(\left[\frac{n}{2}\right]\right)}, v_{1}\right\}$. Selanjutnya, elemen-elemen simpul $S_{1}$ diberi warna 1 sehingga diperoleh kelas warna $K_{1}$ dan elemen-elemen simpul $S_{2}$ diberi warna 2 sehingga diperoleh kelas warna $K_{2}$ sedangkan elemen-elemen simpul $\left.\left\{v_{2}, v_{4}, v_{6}, \ldots, v_{2}\left(\mid \frac{n}{2}\right]\right)\right\}$ diberi warna 3 sehingga diperoleh kelas warna $K_{3}$. Untuk simpul-simpul yang tersisa yaitu $v_{3}, v_{5}, \ldots, v_{2}\left(\left\lfloor\frac{n}{2}\right\rfloor-1\right)+1$ dan satu simpul $u_{n}$ belum terwarnai, masing-masing simpul diberi warna berbeda yaitu $4,5, \ldots,\left\lfloor\frac{n}{2}\right\rfloor+3$ sehingga diperoleh kelas warna $K_{4}=\left\{v_{3}\right\}, K_{5}=\left\{v_{5}\right\}, \ldots, K_{\left\lfloor\frac{n}{2}\right\rfloor+2}=$ $\left\{v_{2\left(\left\lfloor\frac{n}{2}\right\rfloor-1\right)+1}\right\}, K_{\left\lfloor\frac{n}{2}\right\rfloor+3}=\left\{u_{n}\right\}$. Jadi kelas warna yang diperoleh dari graf antiprisma $A_{n}$ yaitu $K_{1}, K_{2}, K_{3}, K_{4}, \ldots, K_{\left\lfloor\frac{n}{2}\right\rfloor+3}$. Dari kelas warna yang diperoleh simpul $u_{1}, v_{1}$ dapat mendominasi $K_{\left\lfloor\frac{n}{2}\right\rfloor+3}$ simpul $u_{2}, v_{2}$ dapat mendominasi $K_{4}$, simpul $u_{3}, v_{3}$ dapat mendominasi $K_{4}$ dan seterusnya simpul $u_{n}, v_{n}$ dapat mendominasi $K_{\left\lfloor\frac{n}{2}\right\rfloor+3}$ artinya, pewarnaan yang diperoleh merupakan dominator coloring. Akibatnya, berdasarkan Definisi 3 diperoleh $\chi_{d}\left(A_{n}\right) \leq\left\lfloor\frac{n}{2}\right\rfloor+3$. Selanjutnya, akan ditunjukkan bilangan dominator chromatic pada graf antiprisma yaitu $\chi_{d}\left(A_{n}\right)=\left\lfloor\frac{n}{2}\right\rfloor+3$. Andaikan $\chi_{d}\left(A_{n}\right)=$ $\left\lfloor\frac{n}{2}\right\rfloor+2$ maka terdapat $\left\lfloor\frac{n}{2}\right\rfloor+2$ kelas warna pada graf $A_{n}$. Akibatnya, pada salah satu kelas warna $K_{j}$ untuk $j=4,5, \ldots,\left\lfloor\frac{n}{2}\right\rfloor+2$ terdapat salah satu $j$ dengan $\left|K_{j}\right|=2$ dan untuk $j$ lainnya $\left|K_{j}\right|=1$. Tanpa mengurangi keumuman, misalkan $K_{4}=\left\{v_{k}, v_{l}\right\}$ untuk $k \neq l$ dengan $k, l=3,5,7, \ldots, 2 i+1$ untuk $i=1,2,3, \ldots, n$ maka simpul $v_{k}$ dan $v_{l}$ tidak dapat mendominasi kelas warna manapun. Hal tersebut kontradiksi dengan Definisi 3. Jadi terbukti $\chi_{d}\left(A_{n}\right)=\left\lfloor\frac{n}{2}\right\rfloor+3$.

\section{Dominator Coloring pada Graf Prisma}

Graf prisma dengan jumlah simpul $3 n$ memiliki pola bilangan dominator chromatic sehingga diperoleh Proposisi 8 berikut.

Proposisi 8. Jika diberikan graf prisma $P_{(n, 3)}$ untuk $n \geq 1$, maka:

$$
\chi_{d}\left(P_{(n, 3)}\right)=\left\{\begin{array}{cl}
3 & n=1,2 \\
n+2 & n \geq 3 .
\end{array}\right.
$$

Bukti: Diberikan graf prisma $P_{(n, 3)}$ untuk $n \geq 1$, diketahui graf prisma terbentuk dari hasil kali Kartesius antar dua buah graf yaitu graf cycle $C_{m}$ untuk $m=3$ dan graf lintasan $P_{n}$, dengan jumlah simpul $3 n$ terdiri dari himpunan simpul $V\left(P_{(n, 3)}\right)=\left\{u_{1}, u_{2}, \ldots, u_{n}, v_{1}, v_{2}, \ldots, v_{n}, w_{1}, w_{2}, \ldots, w_{n},\right\}$, sehingga pada pembuktian ini dapat dibagi menjadi dua kasus.

Kasus 1: jika $n=1,2$

Pada graf $P_{(n, 3)}$ diperoleh himpunan simpul yang mendominasi yaitu $S_{1}=\left\{u_{1}\right\}, S_{2}=\left\{v_{1}\right\}, S_{3}=\left\{w_{1}\right\}$ untuk $n=1$ dan $T_{1}=\left\{u_{1}, v_{2}\right\}, T_{2}=\left\{v_{1}, w_{2}\right\}, T_{3}=\left\{w_{1}, u_{2}\right\}$ untuk $n=2$. Selanjutnya, elemen simpul $S_{1}$ dan $T_{1}$ diberi warna 1 sehingga diperoleh kelas warna $K_{1}$, elemen simpul $S_{2}$ dan $T_{2}$ diberi warna 2 sehingga diperoleh kelas warna $K_{2}$ dan elemen simpul $S_{3}$ dan $T_{3}$ diberi warna 3 sehingga diperoleh kelas warna $K_{3}$. Karena setiap simpul yang bertetangga memiliki warna yang berbeda maka 
pewarnaan tersebut merupakan pewarnaan simpul dengan $\chi\left(P_{(n, 3)}\right)=3$. Akibatnya, berdasarkan Observasi 4 diperoleh $\chi_{d}\left(P_{(n, 3)}\right) \geq 3$. Lebih lanjut, dari kelas warna yang diperoleh untuk $n=1$ masing-masing simpul $u_{1}, v_{1}, w_{1}$ dapat mendominasi setiap simpul dikelas warna $K_{1}, K_{2}, K_{3}$. Untuk $n=2$ simpul $u_{1}, w_{2}$ dapat mendominasi setiap simpul dikelas warna $K_{3}$, simpul $u_{2}, v_{1}$ dapat mendominasi setiap simpul dikelas warna $K_{1}$ dan simpul $w_{1}, v_{2}$ dapat mendominasi setiap simpul dikelas warna $K_{2}$. Jadi setiap simpul dapat mendominasi beberapa kelas warna, yang artinya pewarnaan yang diperoleh merupakan dominator coloring. Akibatnya, berdasarkan Definisi 3 dan diperoleh $\chi_{d}\left(P_{(n, 3)}\right) \leq 3$. Oleh kerena $\chi_{d}\left(P_{(n, 3)}\right) \geq 3$ dan $\chi_{d}\left(P_{(n, 3)}\right) \leq 3$, maka terbukti $\chi_{d}\left(P_{(n, 3)}\right)=3$

Kasus 2: jika $n \geq 3$

Pada graf prisma diperoleh himpunan simpul yang mendominasi yaitu

$$
\begin{aligned}
& S_{1}=\left\{\begin{array}{cl}
\left\{u_{1}, v_{2}, w_{3}, \ldots, u_{3\left(\frac{n}{3}\right)-2}, v_{3\left(\frac{n}{3}\right)-1}, w_{3\left(\frac{n}{3}\right)}\right\} & n=3 k \\
\left\{u_{1}, v_{2}, w_{3}, \ldots, u_{3\left\lfloor\frac{n}{3}\right\rfloor-2}, v_{3\left\lfloor\frac{n}{3}\right\rfloor-1}, w_{3\left\lfloor\frac{n}{3}\right\rfloor}\right\} \cup\left\{u_{n}\right\} & n=3 k+1 \\
\left\{u_{1}, v_{2}, w_{3}, \ldots, u_{3\left\lfloor\frac{n}{3}\right\rfloor-2}, v_{3\left\lfloor\frac{n}{3}\right\rfloor-1}, w_{3\left\lfloor\frac{n}{3}\right]}\right\} \cup\left\{u_{n-1}, v_{n}\right\} & n=3 k+2
\end{array}\right. \\
& S_{2}=\left\{\begin{array}{cl}
\left\{v_{1}, w_{2}, u_{3}, \ldots, v_{3\left(\frac{n}{3}\right)-2}, w_{3\left(\frac{n}{3}\right)-1}, u_{\left.3\left(\frac{n}{3}\right)\right\}}\right\} & n=3 k \\
\left.\left\{v_{1}, w_{2}, u_{3}, \ldots, v_{3\left\lfloor\frac{n}{3} \mid-2\right.}, w_{3\left\lfloor\frac{n}{3}\right\rfloor-1}, u_{3} \mid \frac{n}{3}\right\}\right\} \cup\left\{v_{n}\right\} & n=3 k+1 . \\
\left\{v_{1}, w_{2}, u_{3}, \ldots, v_{3\left\lfloor\frac{n}{3}\right\rfloor-2}, w_{\left.3 \mid \frac{n}{3}\right\rfloor-1}, u_{\left.3 \mid \frac{n}{3}\right]}\right\} \cup\left\{v_{n-1}, w_{n}\right\} & n=3 k+2
\end{array}\right.
\end{aligned}
$$

Selanjutnya, elemen-elemen simpul $S_{1}$ diberi warna 1 sehingga diperoleh kelas warna $K_{1}$ dan elemenelemen simpul $S_{2}$ diberi warna 2 sehingga diperoleh kelas warna $K_{2}$. Untuk simpul-simpul yang tersisa yaitu $\left\{w_{1}, u_{2}, v_{3}, \ldots, w_{3\left(\frac{n}{3}\right)-2}, u_{3\left(\frac{n}{3}\right)-1}, v_{3\left(\frac{n}{3}\right)}\right\}$ untuk $n=3 k,\left\{w_{1}, u_{2}, v_{3}, \ldots, w_{3\left\lfloor\frac{n}{3}\right\rfloor-2}, u_{3\left\lfloor\frac{n}{3}\right\rfloor-1}, v_{3}\left\lfloor\frac{n}{3}\right\rfloor\right\} \cup$ $\left\{w_{n}\right\}$ untuk $n=3 k+1$ dan $\left\{w_{1}, u_{2}, v_{3}, \ldots, w_{3\left[\frac{n}{3}\right]-2}, u_{3\left[\frac{n}{3}\right]-1}, v_{3\left[\frac{n}{3}\right]}\right\} \cup\left\{w_{n-1}, u_{n}\right\}$ untuk $n=3 k+$ 2 belum terwarnai, masing-masing simpul diberi warna yang berbeda yaitu 3,4,5, ..,n+2, sehingga diperoleh kelas warna yaitu $K_{3}=\left\{w_{1}\right\}, K_{4}=\left\{u_{2}\right\}, K_{5}=\left\{v_{3}\right\}, \ldots, K_{n+2}=\left\{v_{3\left(\frac{n}{3}\right)}\right\}$ untuk $n=3 k$, $K_{3}=\left\{w_{1}\right\}, K_{4}=\left\{u_{2}\right\}, K_{5}=\left\{v_{3}\right\}, \ldots, K_{n+2}=\left\{w_{n}\right\}$ untuk $n=3 k+1$ dan $K_{3}=\left\{w_{1}\right\}, K_{4}\left\{u_{2}\right\}, K_{5}=$ $\left\{v_{3}\right\}, \ldots, K_{n+2}=\left\{u_{n}\right\}$ untuk $n=3 k+2$. Jadi kelas warna yang diperoleh dari graf prisma yaitu $K_{1}, K_{2}, K_{3}, \ldots, K_{n+2}$. Dari kelas warna yang diperoleh simpul $u_{1}, v_{1}, w_{1}$ dapat mendominasi $K_{3}$, simpul $u_{2}, v_{2}, w_{2}$ dapat mendominasi $K_{4}$ dan seterusnya simpul $u_{n}, v_{n}, w_{n}$ dapat mendominasi $K_{n+2}$. Hal tersebut berarti pewarnaan yang didefinisikan merupakan dominator coloring. Akibatnya, berdasarkan Definisi 3 diperoleh $\chi_{d}\left(P_{(n, 3)}\right) \leq n+2$. Selanjutnya, akan ditunjukan bilangan dominator chromatic pada graf prisma yaitu $\chi_{d}\left(P_{(n, 3)}\right)=n+2$. Andaikan $\chi_{d}\left(P_{(n, 3)}\right)=n+1$ maka terdapat $n+1$ kelas warna pada graf prisma. Akibatnya, pada salah satu kelas warna $K_{i}$ untuk $i=3, \ldots, n+1$ terdapat salah satu $k$ dengan $\left|K_{i}\right|=2$ dan untuk $i$ lainnya $\left|K_{i}\right|=1$. Tanpa mengurangi keumuman, misalkan $K_{3}=\left\{w_{j}, u_{m}\right\}$ untuk $j \neq m$ dengan $j, m=1,2,3, \ldots, n$ maka simpul $w_{j}$ dan $u_{m}$ tidak dapat mendominasi kelas warna manapun. Hal tersebut kontradiksi dengan Definisi 3. Jadi terbukti $\chi_{d}\left(P_{(n, 3)}\right)=n+2$.

\section{KESIMPULAN}

Bilangan dominator chromatic adalah jumlah minimum kelas warna yang diperlukan untuk dominator coloring. Bilangan dominator chromatic pada graf cycle, antiprisma dan prisma diperoleh 
dengan cara menentukan jumlah minimum kelas warna dari masing-masing graf. Berdasarkan pada pembahasan sebelumnya maka diperoleh kesimpulan dari penelitian ini adalah sebagai berikut.

a. Bilangan dominator chromatic pada graf cycle:

$$
\chi_{d}\left(C_{n}\right)=\left\{\begin{array}{cc}
2, & n=4 \\
3, & n=5 \\
\left\lceil\frac{n}{3}\right\rceil+2, n \geq 6 & \text { dan } n=3
\end{array}\right.
$$

b. Bilangan dominator chromatic pada graf antiprisma dan graf prisma yaitu :

$$
\chi_{d}\left(A_{n}\right)=\left\{\begin{array}{ll}
3, & n=3 \\
4, & n=4 \\
5, & n=5 \\
\left\lfloor\frac{n}{2}\right\rfloor+3, & n \geq 6
\end{array} \text { dan } \chi_{d}\left(P_{(n, 3)}\right)=\left\{\begin{array}{cl}
3 & n=1,2 \\
n+2 & n \geq 3 .
\end{array}\right.\right.
$$

\section{DAFTAR PUSTAKA}

[1] Haynes TW, Hedetniemi ST dan Slater PJ. Domination in Graphs: Advanced Topics. Marcel Dekker. New York. 1998.

[2] Karbasi AH dan Atani RE. Application of Dominating Sets in Wireless Sensor Networks. International Journal of Secutiry and Its Appli cations. 2013; 7:185-202.

[3] Meng KK, Fengming D dan Guan TE. Introduction To Graph Theory. World scientific. Singapore. 2006.

[4] Kartika F. Pembangunan Perangkat Lunak Pembangkit Jadwal Kuliah dan Ujian Dengan Metode Pewarnaan Graf. Jurnal Buana Informatika. 2006; 1:57-68

[5] Diana LE, Suryaningtyas W dan Suprapti E. Pengaturan Lampu Lalu Lintas di Persimpangan Jalan Ahmad Yani Giant Dengan Aplikasi Pewarnaan Teori Graf. Journal of Mathematics Education, Science and Technology. 2016;1(1):69-85.

[6] Jothiraj R, Jayakumar S dan Venugopal P. Open Shop Scheduling in a Circular Coloring and Dominator Coloring of Circular-Arc Graphs. International Journal of Pure and Applied Mathematics. 2018; 118(10): 185-193

[7] Munir R. Matematika Diskrit Ed ke-3. Informatika. Bandung. 2010.

[8] Gera R, Rasmussen C dan Horton S. Dominator Coloring and Safe Clique Cartitions. Congressus Numerantium. 2006;181: 19-32.

[9] Gera RM. On Dominator Coloring in Graphs. Graph Theory Notes of New York LIT. 2006; 25-30.

[10] Baca M, Bashir F dan Semanicova A. Face Antimagic Labeling of Antiprism.Util. Math. 2011;84: 209-224.

[11] Ismiyanti, Sudarsana IW dan Musdalifah S. Pelabelan Prime Cordial Pada Graf Prisma dan Graf Terhubung Antar Pusat pada Graf Roda. Jurnal Ilmiah Matematika dan Terapan. 2013; 10(1) :43-54.

TOMIPATRA : : Jurusan Matematika FMIPA UNTAN, Pontianak tommypatra11@gmail.com

EVI NOVIANI $\quad$ : Jurusan Matematika FMIPA UNTAN, Pontianak evi_noviani@math.untan.ac.id

FRANSISKUS FRAN : Jurusan Matematika FMIPA UNTAN, Pontianak fransiskusfran@math.untan.ac.id 